\title{
RADIATION MEASUREMENT AT X-RAY CENTRES OF A FEW HOSPITALS IN KATHMANDU CITY, NEPAL.
}

\author{
Karan Giri ${ }^{1}$, Dhiraj Giri ${ }^{2}$, V. Krishna Murthy ${ }^{3}$ \\ ${ }^{1}$ M.Sc. Student, Tribhuvan University, ${ }^{2,3}$ Kathmandu University, Dhulikhel, Kavre, Nepal \\ Corresponding Author E-Mail: vkm@ku.edu.np
}

\begin{abstract}
The ionizing radiation has hazardous health effects upon human exposure. Different types of cancers are reported to be arising on account of overt exposure to ionizing radiation like Xrays. This study reports occupational exposure as well as general exposure to the public and persons visiting radiology department in hospitals of Kathmandu city for diagnostic and therapeutic purposes. A portable environment radiation monitor was used to quantify the total radiation in places of work in the X-ray departments of 13 hospitals located in different parts of city. The findings show increased exposure and in some instances very high levels of unintentional exposure to radiation.
\end{abstract}

\section{INTRODUCTION}

$\mathrm{X}$-rays are electromagnetic waves or photons not emitted from the nucleus, but normally emitted by energy changes in electrons x-rays are radiations possessing high energy and penetrating capacity. They are classified as ionizing radiation and are extensively used for industrial, medical diagnostic and therapeutic purposes. The objectives of the study were to quantify the radiation scatter levels prevalent at x-ray centers of hospitals; to measure radiation emanating from special medical diagnostic and therapeutic machines like CTScanning and Fluoroscopy and also to delineate level of occupational exposure of radiation to which the technician-operators are exposed and to facilitate concerned hospital authority to contemplate on control measures.

\section{MATERIALS AND METHODS}

The radiation survey has been carried out by the measurement of radiation at different points of the diagnostic and therapeutic rooms, control panel and control room of different hospitals.

Radiation measurement procedure: Radiation was measured in x-ray room of 13 different hospitals, fluoroscopy room of 2 hospitals and CT-Scan room of 1 hospital in Kathmandu City, Nepal using a portable radiation measuring instrument LB $1200 \mathrm{RATO} / \mathrm{F}$. The equipment was designed by Laboratorium Prof. Brethold, Germany. Measurement was performed during the daytime between 9AM to $5 \mathrm{PM}$. The background radiation was measured before the machines were switched on in respective rooms. Subsequently after the exposure to the radiation, the fall out radiation was measured in 4 different corners of the radiation facility room of different hospitals. The unit of measurement was in count per minute and converted in millisievert per year $(\mathrm{mSv} / \mathrm{yr})$. 


\section{RESULTS AND DISCUSSION}

The maximum radiation level noted at 4 different corners of radiation machine room was considered for the purpose of statistical analysis. Table-1 presents the mean and median radiation levels observed according to different hospitals.

Table-1:

\section{Mean and median x-radiation levels in radiology section of different hospitals in Kathamandu City}

\begin{tabular}{|c|c|c|c|}
\hline $\begin{array}{l}\text { Name of the } \\
\text { Hospitals }\end{array}$ & $\begin{array}{c}\text { Number of } \\
\text { Observations }\end{array}$ & $\begin{array}{c}\text { Mean } \pm \text { SD } \\
\mathrm{mSv} / \mathrm{yr}\end{array}$ & $\begin{array}{l}\text { Median } \\
\mathrm{mSv} / \mathrm{yr}\end{array}$ \\
\hline Hospital- $X_{1}$ & 4 & $\begin{array}{c}5.50 \pm 0.84 \\
(4.99-6.75)\end{array}$ & 5.13 \\
\hline Hospital- $\mathrm{X}_{2}$ & 4 & $\begin{array}{c}4.38 \pm 0.30 \\
(4.12-4.64)\end{array}$ & 4.38 \\
\hline Hospital- $X_{3}$ & 4 & $\begin{array}{c}3.07 \pm 0.20 \\
(2.89-3.24)\end{array}$ & 3.07 \\
\hline Hospital-X & 4 & $\begin{array}{c}3.51 \pm 0.55 \\
(2.89-4.12)\end{array}$ & 3.50 \\
\hline Hospital-X $\mathrm{X}_{5}$ & 4 & $\begin{array}{c}3.29 \pm 0.36 \\
(2.89-3.77)\end{array}$ & 3.24 \\
\hline Hospital- $_{6}$ & 4 & $\begin{array}{c}3.92 \pm 0.38 \\
(3.50-4.38)\end{array}$ & 3.90 \\
\hline Hospital-X $\mathrm{X}_{7}$ & 4 & $\begin{array}{c}3.66 \pm 0.48 \\
(3.24-4.12)\end{array}$ & 3.64 \\
\hline Hospital-X $\mathrm{X}_{8}$ & 4 & $\begin{array}{c}3.15 \pm 0.37 \\
(2.63-3.50)\end{array}$ & 3.24 \\
\hline Hospital- $\mathrm{X}_{9}$ & 4 & $\begin{array}{c}4.97 \pm 0.65 \\
(4.38-5.87)\end{array}$ & 4.82 \\
\hline Hospital- $\mathrm{X}_{10}$ & 4 & $\begin{array}{c}3.94 \pm 0.90 \\
(2.63-4.64)\end{array}$ & 4.25 \\
\hline Hospital- $\mathrm{X}_{11}$ & 4 & $\begin{array}{l}3.09 \pm 0.31 \\
(2.63-3.24)\end{array}$ & 3.24 \\
\hline Hospital- $\mathrm{X}_{12}$ & 4 & $\begin{array}{c}3.37 \pm 0.15 \\
(3.24-3.50) \\
\end{array}$ & 3.37 \\
\hline Hospital- $\mathrm{X}_{13}$ & 4 & $\begin{array}{c}2.61 \pm 0.25 \\
(2.28-2.89) \\
\end{array}$ & 2.63 \\
\hline
\end{tabular}

(Figures in brackets indicate range)

The instrument used in the present survey was suitable to detect and measure x-rays or gamma rays because these impart energy to charged particles, which cause ionization (Irving Kaplan, 1998).

The doses limits are recommended by ICRP suggest the following: (IAEA-ICRP, 1997)

a. The annual average dose over five years should not exceed $20 \mathrm{mSv}$ for occupational exposure

b. Public should not be exposed to more than an average of $1 \mathrm{mSv}$ per year. 
c. Radon gas in homes: average $2 \mathrm{mSv}$ per year. Usual variation ranges 0.2 to $500 \mathrm{mSv}$ per year.

d. The natural background radiation most regions: 1 to $2 \mathrm{mSv}$ per year; in some cases up to $20 \mathrm{mSv}$ per year

The radiations measured at x-ray departments were beyond the prescribed level of $1 \mathrm{mSv} / \mathrm{yr}$. (for public exposure) in all the hospitals; the median values also surpassed the prescribed dose limit. The level noted among the hospitals ranged between 2.63 to $5.13 \mathrm{mSv} / \mathrm{yr}$.

Mean amount of radiation found in different hospitals was greater than $1 \mathrm{mSv} / \mathrm{yr}$. (for public exposure). The mean observed radiation compared with reference limit for public exposure was higher and the difference between the mean observed and recommended values was statistically significant $(\mathrm{p}<0.05)$.

There is an obvious health risk of radiation exposure for all the exposed population visiting $\mathrm{X}$-radiography department of the hospitals measured. There is however an impending risks of chronic occupational exposure to the employees, technicians and maintenance personnel of these x-ray machines at the respective hospitals. In this scenario, there is a necessity of adequate and appropriate radiation protection at all the hospitals surveyed.

Table-2:

Mean and median radiation levels in Fluoroscopy section of different hospitals in Kathamandu City

\begin{tabular}{|l|c|c|c|}
\hline $\begin{array}{c}\text { Name of the } \\
\text { Hospitals }\end{array}$ & $\begin{array}{c}\text { Number of } \\
\text { Observation }\end{array}$ & $\begin{array}{c}\text { Mean } \pm \mathrm{SD} \\
\mathrm{mSv} / \mathrm{yr}\end{array}$ & $\begin{array}{c}\text { Median } \\
\mathrm{mSv} / \mathrm{yr}\end{array}$ \\
\hline Hospital-F & 3 & $\begin{array}{c}301.69 \pm 73.50 \\
(233.54-379.57)\end{array}$ & 291.97 \\
\hline Hospital-F $_{2}$ & 3 & $\begin{array}{c}486.68 \pm 44.61 \\
(438.00-525.60)\end{array}$ & 496.43 \\
\hline
\end{tabular}

(Figures in brackets indicate range)

The radiation measured in the fluoroscopic section between the two hospitals was beyond the reference dose limit of $1 \mathrm{mSv} / \mathrm{yr}$. The actual exceedance compared to the prescribed limit was about 302 times excess noted in Hospital $-F_{1}$ and about 487 times excess at Hospital $F_{2}$. The exceedance was substantial.

Table-3:

Mean and median radiation levels in CT-Scan section hospital in Kathamandu City

\begin{tabular}{|c|c|c|c|}
\hline $\begin{array}{c}\text { Name of the } \\
\text { Hospitals }\end{array}$ & $\begin{array}{c}\text { Number of } \\
\text { Observation }\end{array}$ & $\begin{array}{c}\text { Mean } \pm \mathrm{SD} \\
\mathrm{mSv} / \mathrm{yr}\end{array}$ & $\begin{array}{c}\text { Median } \\
\mathrm{mSv} / \mathrm{yr}\end{array}$ \\
\hline Hospital-C $_{1}$ & 4 & $\begin{array}{c}2773.26 \pm 1720.14 \\
(876.00-5545.08)\end{array}$ & 2335.99 \\
\hline
\end{tabular}

(Figures in brackets indicate range)

The radiation extent of scatter ness noted at Hospital- $\mathrm{C}_{1}$ in the CT-Scan facility suggests very high exceedance compared to prescribed limit of exposure. It was about 2773 times beyond the limit of $1 \mathrm{mSv} /$ year. 
Another fact was that while the patients in fluoroscopy and CT-Scan facilities have to be inevitably subjected to relatively higher doses of diagnostic as well as therapeutic radiation, the employees involved in operating these equipments are at the risk of exposure to high radiation doses. A comparison made to the occupational exposure limit with the observed doses, it can be stated that the observed levels were much beyond the occupational exposure limit. This suggests the high risk associated to employees and maintenance staff involved in these facilities. Therefore, immediate radiation protection measures to be initiated to the employees (technicians, attendants and maintenance staff) at CT-Scan, Fluoroscopy facility and $\mathrm{x}$-radiology departments of all the hospitals to protect from radiation health hazards. The appraisal of findings and health implications, in small counseling sessions to the employees as well as hospitals concerned is planned.

\section{REFERENCES}

1. Dr. Bjoern Wahlstroem, Radiation, Health and Society, Finland, International1 Atomic Energy Agency (IAEA), 1997

2. Irving Kaplan, Nuclear Physics, Second Edition, India, Narosa Publishing House, 1998. 